\title{
LOW TEMPERATURE STORAGE OF NAA, GA AND 2,4-D TREATED CITRUS BUDSTICKS
}

\author{
Luiz Carlos Chamhum Salomão ${ }^{1 *}$; Dalmo Lopes de Siqueira ${ }^{1}$; Sebastião Fernando Ferreira \\ Lima $^{2}$; Paulo Roberto Cecon ${ }^{3}$; José Maria Moreira Dias ${ }^{1}$; Victor Martins Maia ${ }^{4}$ \\ ${ }^{1}$ UFV - Depto. de Fitotecnia - 36570-000 - Viçosa, MG - Brasil. \\ ${ }^{2}$ ITERACRE - 69908-970 - Rio Branco, AC - Brasil. \\ ${ }^{3} U F V$ - Depto. de Informática - 36570-000 - Viçosa, MG - Brasil. \\ ${ }^{4}$ Unimontes - Depto. de Ciências Agrárias, R. Reinaldo Viana, 2630 - 39440-000 - Janaúba, MG - Brasil. \\ *Corresponding author <lsalomao@ufv.br>
}

\begin{abstract}
Cold storage allows citrus budstick conservation for several months, although gradual bud viability loss and abscission of leaf petioles is observed. This study aimed to maintain bud viability reducing leaf petiole abscission in budsticks of 'Baianinha' and 'Valencia' sweet oranges $(C$. sinensis Osbeck), 'Tahiti' lime (C. latifolia Tanaka), and 'Murcott' tangor (C. sinensis $\times$ C. reticulata), using NAA, $\mathrm{GA}_{3}, 2,4-\mathrm{D}$, and low temperature storage. After a 15-minutes-immersion in distilled water and NAA and $\mathrm{GA}_{3}$ solutions at concentrations of $10,100,500$ and $1000 \mu \mathrm{mol} \mathrm{L}^{-1}$, and 2,4-D solutions at concentrations of $1,10,50$ and $100 \mu \mathrm{mol} \mathrm{L}^{-1}$, the shoots were stored in polyethylene bags at $5 \pm 1{ }^{\circ} \mathrm{C}$ for 74 days. Percentage of leaf petiole abscission, fresh and dry matter losses, bud viability, and growth flush were evaluated. NAA and 2,4-D had the highest efficiency for petiole abscission inhibition, reaching almost $99 \%$ of success. The packaging system and shoot storage under low temperature efficiently reduced fresh and dry matter losses. Bud viability of 'Baianinha', 'Valencia' and 'Murcott' shoots was not reduced by storage, maintaining above $95 \%$ of grafting success. NAA, GA 3 and 2,4$\mathrm{D}$ treatments had no influence on sprout growth.
\end{abstract}

Key words: growth regulator, abscission, propagation

\section{ARMAZENAMENTO EM BAIXA TEMPERATURA DE HASTES PORTA-BORBULHAS DE CITROS TRATADAS COM ANA, GA E 2,4-D}

\begin{abstract}
RESUMO: O armazenamento refrigerado possibilita a conservação de hastes porta-borbulhas de citros por vários meses, embora ocorra perda gradual da viabilidade das borbulhas e abscisão dos pecíolos foliares. Este estudo objetivou manter a viabilidade das borbulhas e reduzir a abscisão dos pecíolos foliares das hastes porta-borbulhas das laranjeiras 'Baianinha' e 'Valência' ( $C$. sinensis Osbeck), da lima ácida 'Tahiti' $(C$. latifolia Tanaka) e da tangoreira 'Murcote' $(C$. sinensis $\times$ C. reticulata) por meio do tratamento com ANA, $\mathrm{GA}_{3}, 2,4-\mathrm{D}$ e armazenamento refrigerado. As hastes foram imersas por 15 minutos em água destilada e em soluções com os reguladores de crescimento ANA e GA 3 nas concentrações $10,100,500$ e $1000 \mu \mathrm{mol} \mathrm{L} \mathrm{L}^{-1}$ e 2,4-D nas concentrações $1,10,50$ e $100 \mu \mathrm{mol} \mathrm{L}^{-1}$ e armazenadas em sacos de polietileno a $5 \pm 1^{\circ} \mathrm{C}$, por 74 dias. Foram avaliados a percentagem de abscisão dos pecíolos foliares, a perda de massa da matéria fresca e seca das hastes, a viabilidade das borbulhas e o crescimento das brotações. ANA e 2,4-D controlaram até $99 \%$ da abscisão dos pecíolos. O sistema de acondicionamento e o armazenamento em baixa temperatura mostraram-se eficientes na redução das perdas de massa de matéria fresca e seca. $\mathrm{O}$ armazenamento não reduziu a viabilidade das borbulhas das laranjeiras 'Baianinha' e 'Valência', e nem da tangoreira 'Murcote', cujo pegamento de enxertia foi superior a 95\%. Os tratamentos com ANA, GA 3 e 2,4-D não influenciaram o crescimento das brotações. Palavras-chave: regulador de crescimento, abscisão, propagação
\end{abstract}

\section{INTRODUCTION}

It is not always possible to obtain an adequate synchronism between the shoot maturation period and bud demand of plants selected for bud production. Thus, it is necessary to store budsticks to maximize bud use, increase offer period, and enhance labor in- put. Cold storage allows budstick conservation for several months, although a gradual bud viability loss is observed. In addition, abscission of leaf petioles is usually observed a few days after cold chamber storage.

Ethylene is the first regulator of the abscission process and its effect is inhibited by auxins. In active leaves auxins inhibit abscission keeping the abscission 
zone cells insensitive to ethylene. Petiole abscission occurs when the leaf blade (where auxin is synthesized) is removed during budstick preparation. Application of exogenous auxins on petioles and leaf blades delays abscission; however, very high concentrations stimulate ethylene production and plant defoliation (Taiz \& Zeiger, 2004). Gibberellins, in some instances, may reduce protein degradation and delay petiole senescence and fruit ripening; in others, they can stimulate or even have no effect on leaf abscission (Arteca, 1995).

The use of growth regulators to control abscission has been tested for several species, such as apples (Marini et al., 1990), macadamia nuts (Nagao \& Sakai, 1985), coffee (Ortega, 1983), and bell pepper (Wien \& Zhang, 1991); however, no information is available for their use to control leaf petiole abscission in citrus shoots.

The objective of this study was to maintain the viability and reduce the abscission of leaf petioles of citrus budsticks, cultivars 'Baianinha,' 'Valencia', 'Tahiti,' and 'Murcott', using $\alpha$-naphthalene acetic acid (NAA), gibberellic acid ( $\left.\mathrm{GA}_{3}\right), 2,4$ dichlorophenoxiacetic acid $(2,4-\mathrm{D})$, and low temperature storage.

\section{MATERIAL AND METHODS}

Budsticks of 'Baianinha' and 'Valencia' sweet oranges $(C$. sinensis Osbeck), 'Murcott' tangor $(C$. sinensis $\times C$. reticulata), and 'Tahiti' lime (C. latifolia Tanaka) were harvested on 08/29/2000 from budstick increase blocks, in Viçosa, Minas Gerais State, Brazil, $\left(20^{\circ} 45^{\prime} \mathrm{S}, 42^{\circ} 52^{\prime} \mathrm{W}\right.$, altitude $\left.648 \mathrm{~m}\right)$. Budsticks of the most recent growth flush were selected since these are the most used in the region of this study. They were harvested 90 days after plant pruning, except for the 'Tahiti' lime, which was harvested 60 days after pruning.

Shoots with ten buds and $5 \mathrm{~mm}$ long petioles had their leaves removed and were grouped into bundles of six, washed in deionized water, disinfected by immersion in a commercial solution of sodium hypochlorite at $1 \%$ active chloride during 15 minutes, and washed again in deionized water. They were later immersed in a fungicide benomyl solution ( $5 \mathrm{~g}$ of the active ingredient per $10 \mathrm{~L}$ of water) during $15 \mathrm{~min}$.

After drying, bundles were individually immersed in distilled water and NAA and $\mathrm{GA}_{3}$ solutions, at concentrations of $10,100,500$, and $1000 \mu \mathrm{mol} \mathrm{L}^{-1}$, and 2,4-D solutions of $1,10,50$ and $100 \mu \mathrm{mol} \mathrm{L}^{-1}$, during $15 \mathrm{~min}$ in a dark room to prevent auxin degradation and shoot bundles were thereafter packed into low density polyethylene transparent bags $(20 \mathrm{~cm} \times$
$30 \mathrm{~cm}$ and $0.015 \mathrm{~mm}$ thickness), and stored at $5 \pm$ $1^{\circ} \mathrm{C}$, for 74 days. Bud viability was tested by grafting on 'Rangpur' lime ( $C$. limonia Osbeck) rootstocks.

NAA and $\mathrm{GA}_{3}$ effects were evaluated in a factorial scheme, four (cultivars) $\times$ two (growth regulators) $\times$ five (concentrations) in a randomized block design, with four replicates. The 2,4-D effect was separately analyzed in a factorial scheme, four (cultivars) $\times$ five (concentrations), in a randomized block design, with four replicates. Other two treatments were added, one (control 1), with shoots collected with the others and used to determine the initial dry matter mass (DMM) percentage, and the second (control 2), with shoots collected 74 days after the others, on the day the stored buds were grafted, and were used to evaluate the effect of the treatments.

Fresh matter mass (FMM) loss \% of shoots after storage; DMM loss \% of control-shoots (controls 1 and 2) and stored shoots; abscission control of leaf petioles of budsticks after storage; bud viability and sprout growth after budding were evaluated. FMM loss was determined by evaluating shoot bundle mass at the beginning and end of the storage period. Shoot FMM loss was calculated by the difference between initial and final masses.

To determine shoot DMM percentages of control 1, control 2 and of those submitted to treatments, composite samples of each shoot bundle were weighed, around $10 \mathrm{~g}$ each, and then dried at $75^{\circ} \mathrm{C}$ until constant weight. Petiole abscission control was expressed as the percentage of petioles fixed on the budsticks. At the end of the storage period, the shoots were vertically dropped one by one, from a height of approximately $10 \mathrm{~cm}$ and the remained fixed petioles were counted. After 74 days of storage, 12 buds of each cultivar (two buds from the same shoot) were grafted (inverted T-budding) on six 'Rangpur' lime rootstocks, spaced $5 \mathrm{~cm}$ apart from each other and on the same side of the rootstock, the lowest being $10 \mathrm{~cm}$ above the soil.

A randomized block design with four replicates was used to test bud viability, with the grafting being performed on days 10 and 11/Nov/2000. The graftings were tied with transparent polyethylene tape, which was removed 21 days after grafting. Successful grafting was evaluated 28 days after by counting the number of survived buds, i.e., buds that were green and fixed to the rootstock. Rootstocks were decapitated as a bisel, approximately $5 \mathrm{~cm}$ above the upper graft and sprout growth was evaluated 90 days after grafting by measuring their length.

Percentage of total soluble sugar and starch in the bark and wood of the budsticks was determined for the shoots treated with $1000 \mu \mathrm{mol} \mathrm{L} \mathrm{L}^{-1}$ of NAA, $1000 \mu \mathrm{mol} \mathrm{L}{ }^{-1}$ of $\mathrm{GA}_{3}, 100 \mu \mathrm{mol} \mathrm{L} \mathrm{L}^{-1}$ of $2,4-\mathrm{D}$, im- 
mersed in deionized water (control-treatment, named control 0), and shoots collected on the budding day (control 2) of 'Baianinha' and 'Valencia' oranges and 'Murcott' tangor. 'Tahiti' lime was not analyzed due to the deterioration observed in the shoots during storage. Treatments were arranged in a $3 \times 3$ factorial scheme, in a randomized block design, with three replicates. The control-treatment (control 0) analysis was descriptive. Bark and wood samples were removed for carbohydrate analysis. Total soluble sugar extraction and quantification were performed according to McCready et al. (1950), modified by Patel (1970) and Hogde \& Hofreiter (1962).

The data were interpreted by means of variance and regression analyses. Mean values of qualitative factors were compared by the Tukey and Dunnett $(p<0.05)$ tests. The statistical analysis was performed using the Genetics and Statistics Analysis System, SAEG V. 5.0 (Funarbe, 1993). Regardless of being significant or not, the triple interaction growth regulators $(\mathrm{R}) \times$ concentration $(\mathrm{C}) \times$ cultivar $(\mathrm{V})$ was unfolded.

\section{RESULTS AND DISCUSSION}

Bud viability was maintained above $95 \%$ in most treatments, even for the 74-day storage period
(Table 1), and did not differ from the average of the controls whose buds were collected on the grafting day. No differences were found in the behavior of the citrus species, or of the different growth regulators, concerning bud viability. The high grafting success index reveals the efficacy of the shoot storage system used in this study. Maciel (2006) maintained viable shoots of 'Valencia' sweet orange and 'Montenegrina' mandarin for 180 days at $5^{\circ} \mathrm{C}$, without the use of growth regulators. Gomes (2004) also maintained viable shoots of 'Pêra Rio' sweet orange treated with $20 \mu \mathrm{mol} \mathrm{L} \mathrm{L}^{-1}$ of $2,4-\mathrm{D}$ for 120 days at $5^{\circ} \mathrm{C}$, but there was reduction in the viability of 'Baianinha' sweet orange shoots after the same storage period.

Contrary to other cultivars, the 'Tahiti' lime showed signs of deterioration 65 days after the beginning of storage, with darkening of the tissues of the budstick extremities. With time, a generalized darkening and growth of fungal mycelium occurred, resulting in loss of some plots. Thus, only the shoots that had a healthy aspect were selected for grafting. For this cultivar, a descriptive analysis of grafting success was performed (Table 1). Bissoli (1986) stored shoots of several citrus species during 63 days at 5 and $8^{\circ} \mathrm{C}$ and also observed darkening followed by deterioration of 'Tahiti' lime shoots. Since the 'Tahiti' lime has a

Table 1 - Percentage of bud viability of 'Baianinha' and 'Valencia' sweet oranges, 'Murcott' tangor, and 'Tahiti' lime, grafted on 'Rangpur' lime rootstocks after treatments with NAA, GA $, 2,4-\mathrm{D}$, submitted to storage in cold chamber at $5^{\circ} \mathrm{C}$ for 74 days.

\begin{tabular}{|c|c|c|c|c|}
\hline \multirow{2}{*}{ Treatment } & \multicolumn{4}{|c|}{ Cultivars } \\
\hline & 'Baianinha' & 'Valencia' & 'Murcott' & 'Tahiti' \\
\hline \multicolumn{5}{|l|}{ growth regulator/ $\mu \mathrm{mol} \mathrm{L}^{-1}$} \\
\hline Control 2 & 100.00 & 100.00 & 96.00 & 100.00 \\
\hline NAA 0 & $95.83^{\text {ns }} \mathrm{A}$ & $97.91^{\mathrm{ns}} \mathrm{A}$ & $97.91^{\text {ns }} \mathrm{A}$ & $91.67 \pm 11.79^{1}$ \\
\hline NAA 10 & $93.75^{\text {ns }} A$ & $100.00^{\text {ns }} \mathrm{A}$ & $97.91^{\text {ns }} \mathrm{A}$ & $70.83 \pm 17.68$ \\
\hline NAA 100 & $100.00^{\text {ns }} \mathrm{A}$ & $97.91^{\mathrm{ns}} \mathrm{A}$ & $89.58^{\text {ns }} \mathrm{A}$ & $67.00 \pm 0.00$ \\
\hline NAA 500 & $100.00^{\text {ns }} \mathrm{A}$ & $100.00^{\text {ns }} \mathrm{A}$ & $100.00^{\text {ns }} \mathrm{A}$ & $91.67 \pm 11.79$ \\
\hline NAA 1000 & $97.91^{\text {ns }} \mathrm{A}$ & $100.00^{\text {ns }} \mathrm{A}$ & $100.00^{\text {ns }} \mathrm{A}$ & $92.00 \pm 0.00$ \\
\hline $\mathrm{GA}_{3} 0$ & $93.74^{\mathrm{ns}} \mathrm{A}$ & $100.00^{\text {ns }} \mathrm{A}$ & $91.66^{\text {ns }} A$ & $96.00 \pm 5.66$ \\
\hline $\mathrm{GA}_{3} 10$ & $93.74^{\text {ns }} \mathrm{A}$ & $97.91^{\text {ns }} \mathrm{A}$ & $93.74^{\mathrm{ns}} \mathrm{A}$ & $96.00 \pm 5.66$ \\
\hline $\mathrm{GA}_{3} 100$ & $100.00^{\text {ns }} \mathrm{A}$ & $97.91^{\text {ns }} A$ & $97.91^{\text {ns }} \mathrm{A}$ & $87.50 \pm 17.68$ \\
\hline $\mathrm{GA}_{3} 500$ & $91.66^{\mathrm{ns}} \mathrm{A}$ & $95.83^{\mathrm{ns}} \mathrm{A}$ & $95.83^{\mathrm{ns}} \mathrm{A}$ & $79.50 \pm 17.68$ \\
\hline $\mathrm{GA}_{3} 1000$ & $83.33^{\text {ns }} \mathrm{AB}$ & $97.91^{\text {ns }} A$ & $81.25^{\mathrm{ns}} \mathrm{B}$ & $91.67 \pm 11.79$ \\
\hline $2,4-\mathrm{D} 0$ & $100.00^{\text {ns }} \mathrm{A}$ & $93.74^{\text {ns }} A$ & $97.91^{\text {ns }} A$ & $96.00 \pm 5.66$ \\
\hline $2,4-\mathrm{D} 1$ & $100.00^{\text {ns }} \mathrm{A}$ & $100.00^{\text {ns }} \mathrm{A}$ & $100.00^{\text {ns }} \mathrm{A}$ & $75.17 \pm 11.55$ \\
\hline 2,4-D 10 & $93.75^{\text {ns }} \mathrm{A}$ & $97.91^{\text {ns }} \mathrm{A}$ & $97.91^{\text {ns }} \mathrm{A}$ & $96.00 \pm 05.66$ \\
\hline $2,4-\mathrm{D} 50$ & $97.91^{\text {ns }} \mathrm{A}$ & $97.91^{\text {ns }} A$ & $95.83^{\text {ns }} \mathrm{A}$ & $91.67 \pm 11.79$ \\
\hline 2,4-D 100 & $100.00^{\mathrm{ns}} \mathrm{A}$ & $97.91^{\mathrm{ns}} \mathrm{A}$ & $93.74^{\mathrm{ns}} \mathrm{A}$ & $96.00 \pm 5.66$ \\
\hline
\end{tabular}

Mean values followed by the same letters in the line did not differ at the Tukey test $(p<0.05)$. Control $2=$ shoots collected on budding

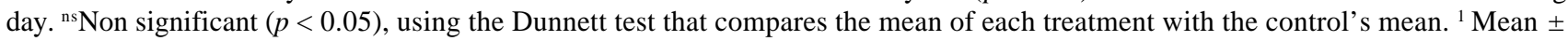
standard deviation. 
tropical origin, the deterioration could have been caused by cold injury at $5^{\circ} \mathrm{C}$, leading to alterations in the cell membranes and electrolyte leakage, which served as substrate for the growth of saprophyte fungus. The infected shoots were analyzed, but it was not possible to determine the fungus species.

The growth regulators did not affected bud viability of the 'Tahiti' lime and the overall the percentage of survived buds was $88 \%$ (Table 1). Bud viability maintenance is due to change of the atmosphere around the shoots by the polyethylene bags, and low storage temperatures. Besides reducing the metabolic rates, this condition reduced the vapor pressure deficit and shoot transpiration. However, Gomes (2004) observed reduction in bud viability of 'Tahiti' lime treated with $20 \mu \mathrm{mol} \mathrm{L} \mathrm{L}^{-1}$ of 2,4-D, after 60 days of storage at $5^{\circ} \mathrm{C}$.

The retention of the leaf petioles in the budsticks of 'Baianinha' orange after 74 days of storage increased linearly as the NAA concentrations increased. So, $1000 \mu \mathrm{mol} \mathrm{L}{ }^{-1}$ maintained $94 \%$ of the petioles adhered to the shoots, while only $44 \%$ were retained in the non-treated shoots (Figure 1). Similar results were also observed for 'Baianinha' and 'Valencia' sweet oranges treated with 2,4-D (Figure 2).
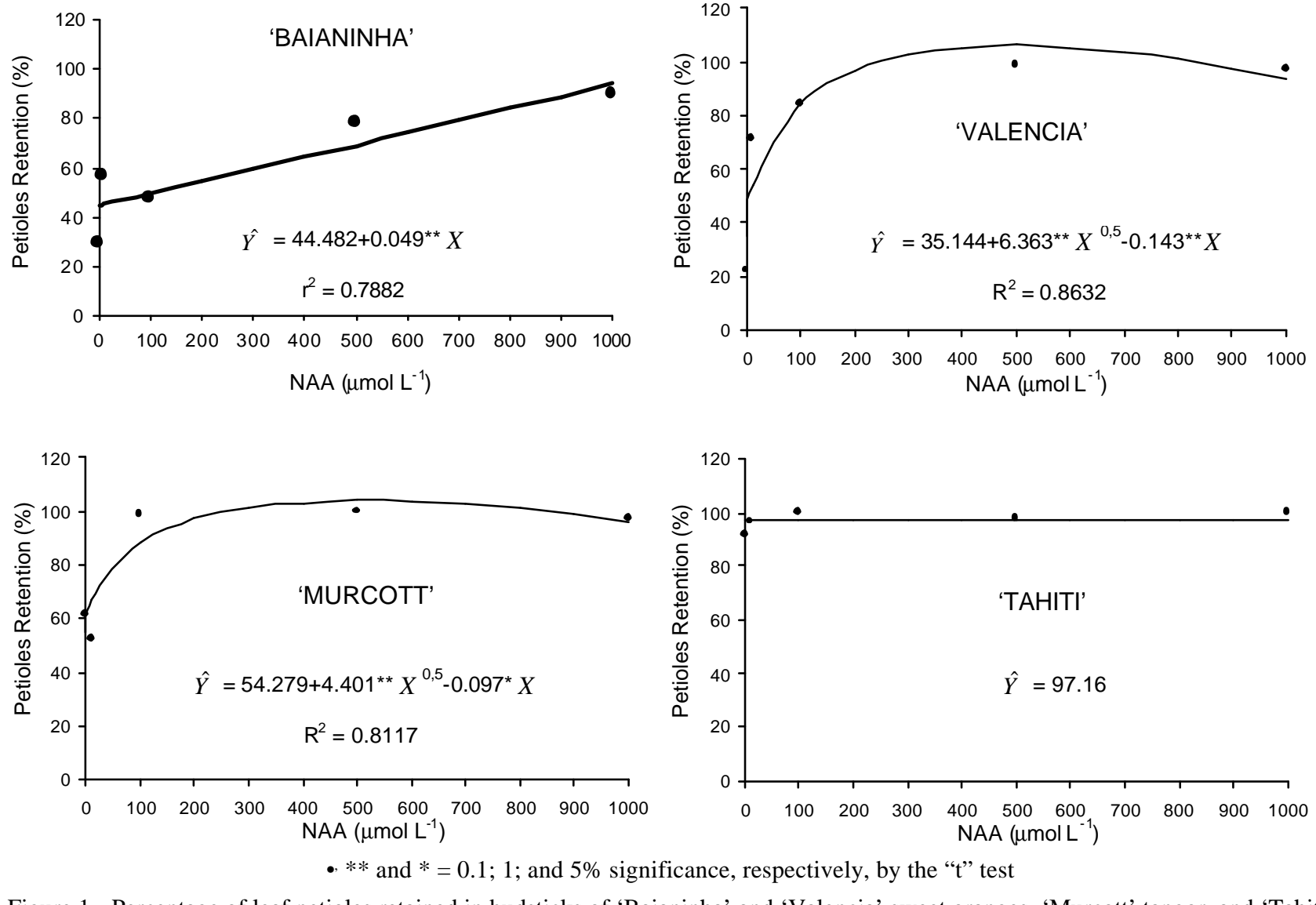

Figure 1 - Percentage of leaf petioles retained in budsticks of 'Baianinha' and 'Valencia' sweet oranges, 'Murcott' tangor, and 'Tahiti' lime, treated with different NAA concentrations.

'Valencia' sweet orange also responded to NAA application. Only $35 \%$ of the petioles were retained in the non-treated shoots. On the other hand, from the $200 \mu \mathrm{mol} \mathrm{L} \mathrm{L}^{-1}$ concentration, that inhibited $96 \%$ of the petiole abscission, the retention process stabilized with no further significant gain. This result is similar to that obtained with the 'Murcott' tangor, for which $200 \mu \mathrm{mol} \mathrm{L}^{-1}$ retained $97 \%$ of the petioles, with stabilization occurring from this point on (Figure 1). In 'Murcott' tangor, only $57 \%$ of the petioles remained attached to the non-treated shoots. Increased 2,4-D concentration up to $20 \mu \mathrm{mol} \mathrm{L} \mathrm{L}^{-1}$ increased petiole retention. From this point on, the percentage of retained petioles stabilized at approximately $92 \%$ (Figure 2). NAA and 2,4-D may reduce the abscission process due to ethylene synthesis inhibition, and consequently, prevent the synthesis of the enzymes responsible for the formation of the abscission layer, such as cellulase and polygalacturonase (Medeiros, 1997).

The stability observed in the petiole retention process with increased concentrations for 'Valencia' and 'Murcott' cultivars treated with NAA, and 'Murcott' treated with 2,4-D, was probably due to the saturation in the linking sites of these growth regula-

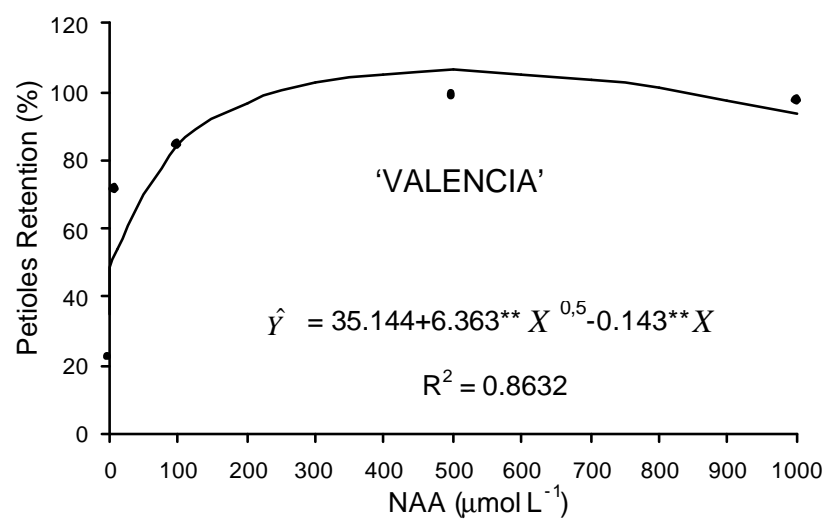



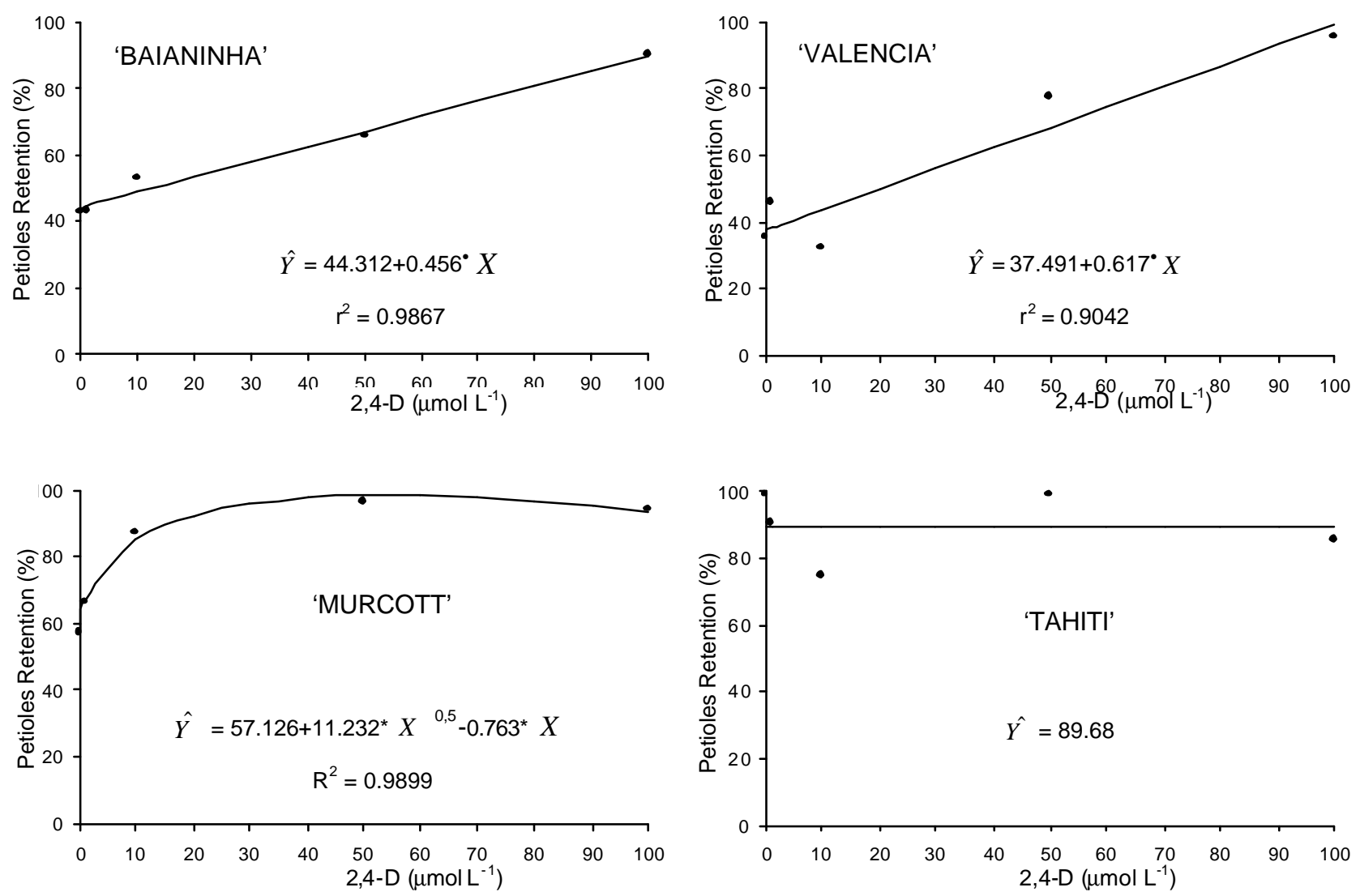

- ** and $*=0,1 ; 1$ and 5\% significance, respectively, by the " $\mathrm{t}$ " test

Figure 2 - Percentage of leaf petioles retained in budsticks of 'Baianinha' and 'Valencia' sweet oranges, 'Murcott' tangor, and 'Tahiti' lime, treated with different 2,4-D concentrations.

tors (Taiz \& Zeiger, 2004). Contrary to the other cultivars, the 'Tahiti' lime did not respond to NAA and 2,4-D applications (Figures 1 and 2). However, the petiole retention indices were similar for all concentrations, presenting overall abscission control means of 97 and $89 \%$, respectively.

There was no effect of $\mathrm{GA}_{3}$ concentrations on petiole retention. 'Tahiti' lime showed the highest retention index $(87 \%)$, although it did not respond to $\mathrm{GA}_{3}$ application. For the remaining cultivars, the retention indices were 41 and $25 \%$ for 'Baianinha' and 'Valencia' sweet oranges, respectively, and $35 \%$ for 'Murcott' tangor, (Figure 3). This behavior may have been the result of ethylene production stimulation by $\mathrm{GA}_{3}$ in the abscission zone (Arteca, 1995), which accelerated the abscission process instead of slowing it down.

'Baianinha' sweet orange shoots, not treated with NAA, had 2.48\% FMM loss. On the other hand, FMM loss was $1 \%$ at $632 \mu \mathrm{mol} \mathrm{L}^{-1}$ (Figure 4). The 'Valencia' cultivar lost $2.75 \%$ of FMM in non-treated shoots. FMM losses were $1.58 \%$ at $200 \mu \mathrm{mol} \mathrm{L}^{-1}$ con-

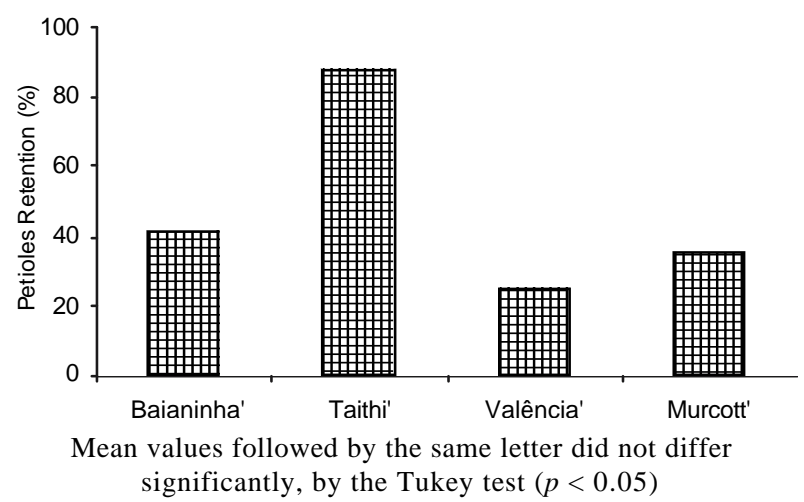

Figure 3 - Retention percentages of leaf petioles of budsticks of 'Baianinha' and 'Valencia' sweet oranges, 'Murcott' tangor, and 'Tahiti' lime, treated with $\mathrm{GA}_{3}$.

centration, and from this point on, the process stabilized as concentration increased. A similar behavior was observed for the 'Murcott' cultivar (Figure 4), which had a $1 \%$ FMM loss, at $200 \mu \mathrm{mol} \mathrm{L}^{-1}$ of NAA. FMM loss of 'Baianinha' sweet orange linearly decreased as 2,4-D concentration increased. At $100 \mu \mathrm{mol} \mathrm{L}^{-1}$, the losses were only $0.9 \%$, while the non-treated shoots 

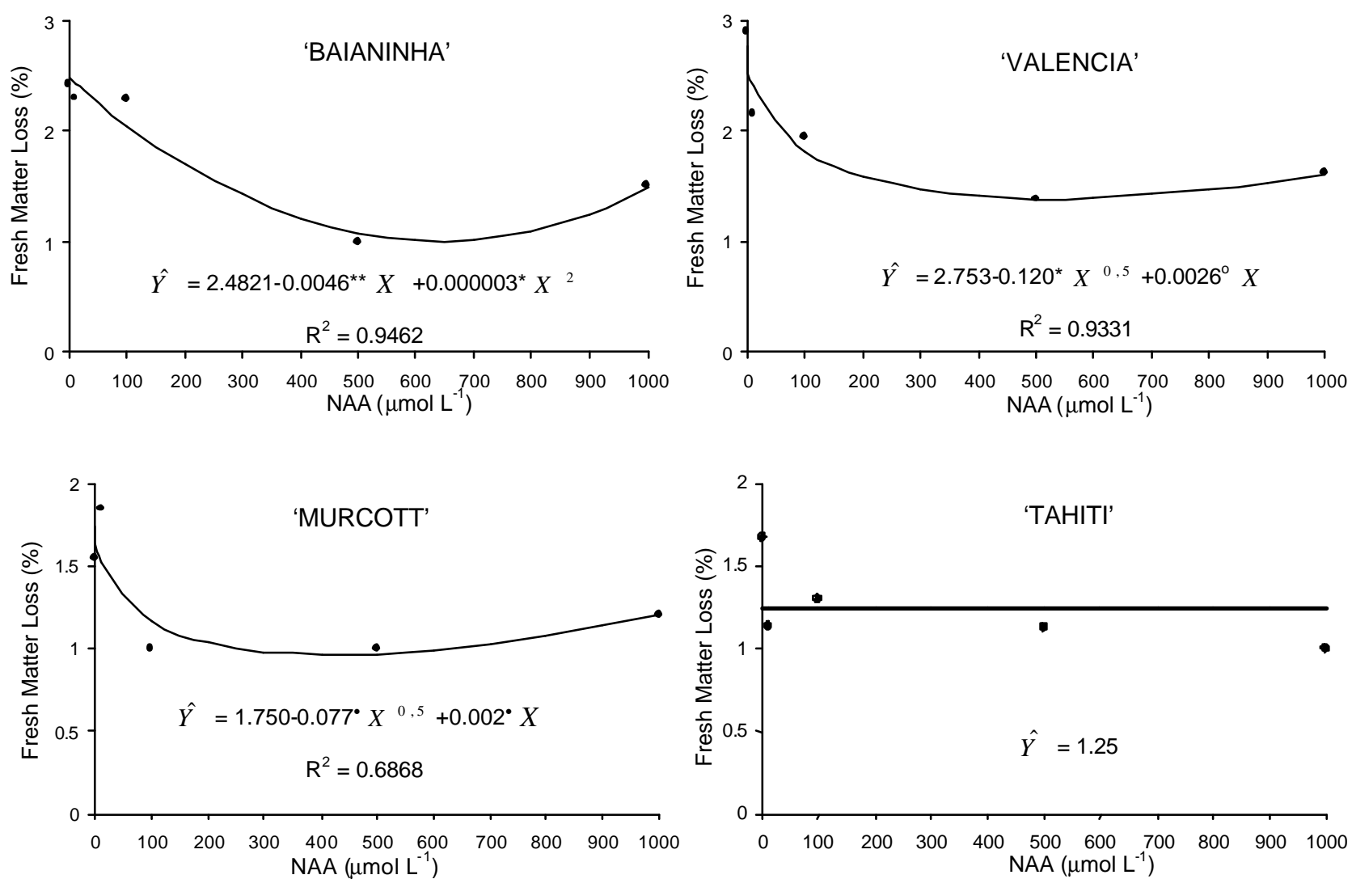

$\bullet, * *$, and $^{\circ}=0,1 ; 1 ; 5$ and $10 \%$ significance, respectively, by the "t" test.

Figure 4 - Fresh matter mass (FMM) loss of budsticks of 'Baianinha' and 'Valencia' sweet oranges, 'Murcott' tangor and 'Tahiti' lime, treated with different NAA concentrations (Data transformed into $\sqrt{x+1}$ ).

lost $2.14 \%$ (Figure 5). 'Valencia' sweet orange had also a linear behavior, at $100 \mu \mathrm{mol} \mathrm{L} \mathrm{L}^{-1}$ of $2,4-\mathrm{D}$, keeping FMM loss at $1 \%$ (Figure 5).

The 'Tahiti' lime did not respond to NAA and 2,4-D application in relation to FMM loss. The 'Murcott' tangor did not respond to 2,4-D application, either (Figure 5). FMM losses were of $1.25 \%$ for 'Tahiti' lime shoots treated with NAA and $1.82 \%$ for shoots treated with $2,4-\mathrm{D}$, and $1.47 \%$ for 'Murcott' tangor treated with 2,4-D.

$\mathrm{GA}_{3-}$ was not efficient in reducing FMM losses, although such losses were small for all the cultivars, with the highest loss occurring in 'Valencia' orange, $4.47 \%$, and the lowest in 'Tahiti' lime, $1.37 \%$ (Figure 6). The correlation between grafting success and shoot FMM loss, for 'Baianinha' and 'Valencia' oranges, and 'Murcott' tangor was not significant, with a correlation coefficient of $r=0.429$.

The possible cause for a decrease in shoot FMM losses is related to the low storage temperature and use of polyethylene packaging. These two factors contributed to decrease the available $\mathrm{O}_{2}$ concentration and correspondingly increase the $\mathrm{CO}_{2}$ concentration, decreasing the respiration rate and senescence rhythm.
Polyethylene package also maintains the relative humidity at high levels around the shoots, leading to less transpiration and, consequently, less FMM loss (Tessarioli Neto et al., 1998). Blumer (2000) worked with different packaging methods for budsticks of 'Pêra' sweet orange stored in a cold chamber at $8^{\circ} \mathrm{C}$ and obtained $90 \%$ survival for buddings for budsticks packed in polyethylene bags after 63 days of storage, while those packed in perforated polypropylene bags did not maintain viability. 'Murcott' cultivar showed the highest dry matter percentages in all growth regulator concentrations, followed by 'Valencia' and 'Baianinha' oranges. The lowest dry matter percentage was found for the 'Tahiti' lime (Table 2).

No differences were found between the dry matter percentage of control 1 shoots and those submitted to 74-day storage (Table 2), showing that the low temperature storage was efficient in reducing respiration rates, and consequently contributed to maintain bud viability. Also, no growth regulator and concentration effects on shoot dry matter percentage were observed (Table 2). In general, the increase in dry matter percentage in plant tissues after harvest is related to water loss. 
Table 2 - Dry matter percentages of budsticks of 'Baianinha' and 'Valencia' sweet oranges, 'Murcott' tangor, and 'Tahiti' lime after treatments with NAA, GA $3,2,4-\mathrm{D}$, submitted to storage in cold chamber at $5^{\circ} \mathrm{C}$ for 74 days.

\begin{tabular}{|c|c|c|c|c|}
\hline \multirow{2}{*}{ Treatment } & \multicolumn{4}{|c|}{ Cultivars } \\
\hline & 'Baianinha' & 'Valencia' & 'Murcott' & 'Tahiti' \\
\hline growth regulator/ $\mu \mathrm{mol} \mathrm{L} \mathrm{L}^{-1}$ & 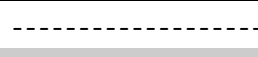 & - & (n-1 & 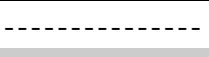 \\
\hline Control 1 & 45.12 & 48.78 & 50.48 & 37.79 \\
\hline NAA 0 & $44.76^{\text {ns }} B C$ & $49.23^{\mathrm{ns}} \mathrm{AB}$ & $53.70^{\mathrm{ns}} A$ & $40.44^{\mathrm{ns}} \mathrm{C}$ \\
\hline NAA 10 & $47.51^{\mathrm{ns}} \mathrm{A}$ & $49.90^{\mathrm{ns}} A$ & $51.41^{\mathrm{ns}} \mathrm{A}$ & $40.40^{\mathrm{ns}} \mathrm{B}$ \\
\hline NAA 100 & $45.93^{\text {ns }} B$ & $49.48^{\mathrm{ns}} \mathrm{AB}$ & $52.88^{\mathrm{ns}} \mathrm{A}$ & $39.54^{\mathrm{ns}} \mathrm{C}$ \\
\hline NAA 500 & $42.12^{\text {ns }} B$ & $49.30^{\mathrm{ns}} \mathrm{A}$ & $51.72^{\mathrm{ns}} A$ & $42.21^{\mathrm{ns}} \mathrm{B}$ \\
\hline NAA 1000 & $45.09^{\text {ns }} B$ & $48.95^{\mathrm{ns}} A B$ & $51.32^{\mathrm{ns}} \mathrm{A}$ & $39.79^{\text {ns }} \mathrm{C}$ \\
\hline $\mathrm{GA}_{3} 0$ & $43.74^{\text {ns }} B C$ & $47.91^{\mathrm{ns}} \mathrm{AB}$ & $51.03^{\mathrm{ns}} \mathrm{A}$ & $40.21^{\text {ns }} \mathrm{C}$ \\
\hline $\mathrm{GA}_{3} 10$ & $46.28^{\mathrm{ns}} A$ & $48.51^{\mathrm{ns}} \mathrm{A}$ & $49.92^{\mathrm{ns}} \mathrm{A}$ & $39.60^{\text {ns }} B$ \\
\hline $\mathrm{GA}_{3} 100$ & $46.91^{\mathrm{ns}} \mathrm{A}$ & $49.08^{\mathrm{ns}} \mathrm{A}$ & $50.88^{\mathrm{ns}} \mathrm{A}$ & $36.90^{\mathrm{ns}} \mathrm{B}$ \\
\hline $\mathrm{GA}_{3} 500$ & $47.30^{\mathrm{ns}} B$ & $48.63^{\mathrm{ns}} \mathrm{AB}$ & $53.87^{\mathrm{ns}} \mathrm{A}$ & $37.80^{\text {ns }} C$ \\
\hline $\mathrm{GA}_{3} 1000$ & $45.27^{\text {ns }} B C$ & $47.75^{\text {ns }} A B$ & $52.52^{\mathrm{ns}} A$ & $40.48^{\mathrm{ns}} \mathrm{C}$ \\
\hline $2,4-\mathrm{D} 0$ & $45.02^{\mathrm{ns}} B$ & $47.30^{\mathrm{ns}} \mathrm{AB}$ & $48.96^{\mathrm{ns}} A$ & $39.41^{\text {ns }} C$ \\
\hline 2,4-D 1 & $44.23^{\text {ns }} \mathrm{C}$ & $47.86^{\mathrm{ns}} B$ & $52.61^{\mathrm{ns}} \mathrm{A}$ & $40.36^{\mathrm{ns}} \mathrm{D}$ \\
\hline 2,4-D 10 & $44.63^{\text {ns }} B$ & $47.98^{\mathrm{ns}} \mathrm{AB}$ & $49.72^{\mathrm{ns}} \mathrm{A}$ & $40.95^{\text {ns }} C$ \\
\hline $2,4-\mathrm{D} 50$ & $45.13^{\mathrm{ns}} \mathrm{B}$ & $47.73^{\mathrm{ns}} \mathrm{B}$ & $51.32^{\mathrm{ns}} \mathrm{A}$ & $39.54^{\text {ns }} C$ \\
\hline 2,4-D 100 & $44.67^{\text {ns }} B$ & $50.17^{\text {ns }} A$ & $49.74^{\text {ns }} \mathrm{A}$ & $40.56^{\text {ns }} \mathrm{C}$ \\
\hline
\end{tabular}

Mean values followed by the same letters on the lines did not differ at the Tukey test $(p<0.05)$. Control $1=$ shoot dry matter percentage on harvesting day, i.e., before storage in cold chamber. $\left.{ }^{\text {ns Non significant }(~} p<0.05\right)$ using the Dunnett test that compares the mean of each treatment with the control mean.
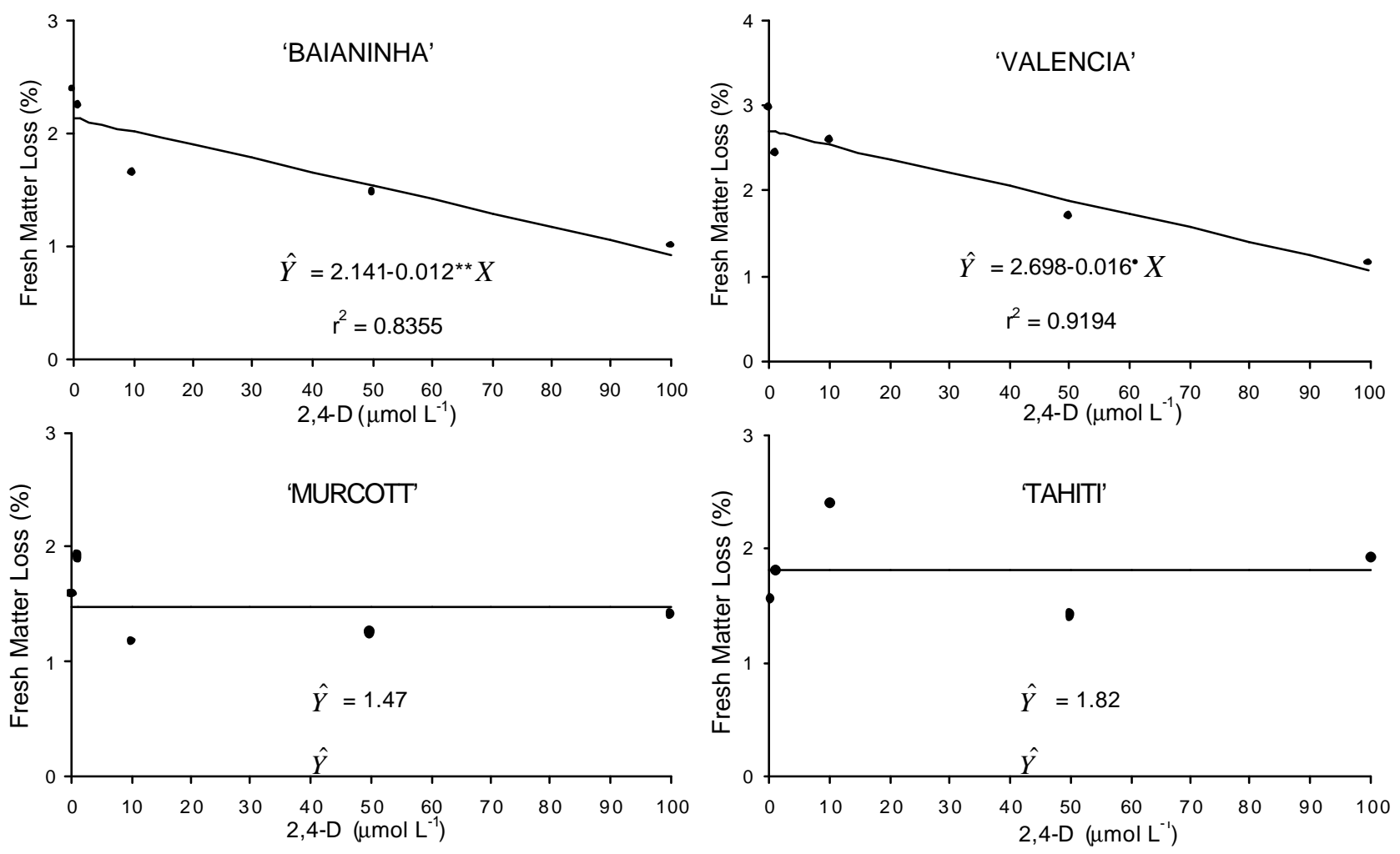

$\bullet, * *$ and $^{\circ}=0,1 ; 1 ; 5$ e $10 \%$ significance, respectively, by the "t" test.

Figure 5 - Fresh matter mass (FMM ) loss of budsticks of 'Baianinha' and 'Valencia' sweet oranges, 'Murcott' tangor, and 'Tahiti' lime, treated with different 2,4-D concentrations (Data transformed into $\sqrt{x+1}$ ). 
There was no effect of growth regulators or their concentrations on sprout growth. 'Baianinha' and 'Valencia' oranges, and 'Tahiti' lime showed higher sprout growth than the 'Murcott' tangor (Table 3). The more vigorous sprout development of 'Baianinha' and 'Valencia' oranges, and for 'Tahiti' lime in relation to the 'Murcott' tangor is possibly due to genotypic differences between species (Lichtemberg, 1981; Ramalho Sobrinho, 1986).

Growth regulators did not affect sprout development probably because the concentrations were so low that they did not interfere in the process. According to Castro \& Vieira (2001), the ideal concentrations for cell elongation vary according to the type of plant tissue, since different plant organs have different sensitivities to auxin concentrations. In addition, sprouting buds are auxin synthesis centers.

Among the treatments, $\mathrm{GA}_{3}$ maintained the highest total soluble sugar percentage in the bark (5.41\% for 'Baianinha', $4.97 \%$ for 'Valencia', and $5.44 \%$ for 'Murcott'). Regarding the total soluble sugar percentage in the wood, growth regulators had a significant effect on the 'Baianinha' cultivar, with $\mathrm{GA}_{3}$ and 2,4-D being the best treatments $(3.46 \%$ and $3.55 \%$, respectively). Independently of which growth regula- tor was used, 'Baianinha' presented higher total sugar percentage $(5.13 \%$ in the bark, and $3.51 \%$ in the wood, on average) in relation to the other cultivars (4.94\% in the bark, and $2.91 \%$ in the wood, on average). For the 'Valencia' cultivar, the highest total sugar concentration in the wood was obtained for the $\mathrm{GA}_{3}$ $(3.28 \%)$ treatment, with an $18 \%$ increase in relation to the control $(2.78 \%)$. For the 'Murcott' tangor, the highest total soluble sugar percentage was observed with 2,4-D (3.11\%).

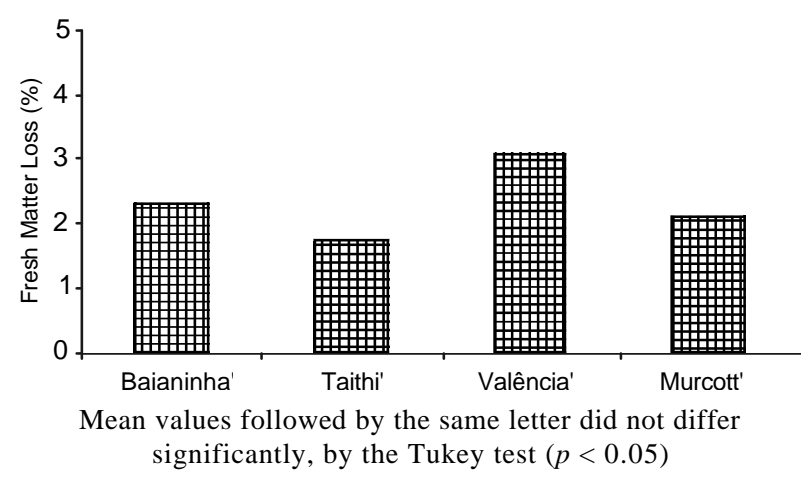

Figure 6 - Percentage values of fresh matter mass (FMM) loss of budsticks of 'Baianinha' and 'Valencia' sweet oranges, 'Murcott' tangor, and 'Tahiti' lime, treated with giberelic acid $\left(\mathrm{GA}_{3}\right)$.

Table 3 - Length (cm) of bud sprouts of 'Baianinha' and 'Valencia' sweet oranges, 'Murcott' tangor, and 'Tahiti' lime, treated with NAA, $\mathrm{GA}_{3}, 2,4-\mathrm{D}$, submitted to storage in cold chamber at $5^{\circ} \mathrm{C}$ for 74 days, 90 days after grafting on 'Rangpur' lime.

\begin{tabular}{|c|c|c|c|c|}
\hline \multirow{2}{*}{ Treatment } & \multicolumn{4}{|c|}{ Cultivars } \\
\hline & 'Baianinha' & 'Valencia' & 'Murcott' & 'Tahiti' \\
\hline growth regulator/ $\mu \mathrm{mol} \mathrm{L} \mathrm{L}^{-1}$ & (n- & - & (n) & (- \\
\hline Control 2 & 20.51 & 19.90 & 17.16 & $29.44 \pm 04.29^{1}$ \\
\hline NAA 0 & $27.87^{\mathrm{ns}} \mathrm{A}$ & $23.08^{\mathrm{ns}} B$ & $18.32^{\text {ns }} B$ & $25.77 \pm 02.03$ \\
\hline NAA 10 & $22.68^{\text {ns }} \mathrm{A}$ & $20.64^{\text {ns }} A$ & $19.34^{\text {ns }} A$ & $22.25 \pm 10.30$ \\
\hline NAA 100 & $24.58^{\mathrm{ns}} \mathrm{AB}$ & $26.62^{\mathrm{ns}} \mathrm{A}$ & $16.41^{\mathrm{ns}} \mathrm{B}$ & $21.37 \pm 14.67$ \\
\hline NAA 500 & $22.17^{\mathrm{ns}} \mathrm{A}$ & $23.54^{\mathrm{ns}} \mathrm{A}$ & $18.92^{\text {ns }} A$ & $35.46 \pm 03.40$ \\
\hline NAA 1000 & $22.62^{\mathrm{ns}} A$ & $18.36^{\mathrm{ns}} A$ & $14.37^{\mathrm{ns}} \mathrm{A}$ & $26.72 \pm 02.51$ \\
\hline $\mathrm{GA}_{3} 0$ & $23.55^{\text {ns }} A$ & $22.97^{\mathrm{ns}} \mathrm{A}$ & $18.33^{\mathrm{ns}} \mathrm{A}$ & $22.65 \pm 16.15$ \\
\hline $\mathrm{GA}_{3} 10$ & $28.26^{\mathrm{ns}} \mathrm{A}$ & $25.78^{\text {ns }} A$ & $16.04^{\text {ns }} B$ & $24.29 \pm 4.29$ \\
\hline $\mathrm{GA}_{3} 100$ & $20.42^{\mathrm{ns}} \mathrm{A}$ & $24.02^{\text {ns }} A$ & $14.73^{\text {ns }} \mathrm{A}$ & $18.73 \pm 0.10$ \\
\hline $\mathrm{GA}_{3} 500$ & $22.71^{\mathrm{ns}} \mathrm{A}$ & $20.12^{\text {ns }} A B$ & $11.46^{\mathrm{ns}} \mathrm{B}$ & $05.52 \pm 1.37$ \\
\hline $\mathrm{GA}_{3} 1000$ & $20.67^{\mathrm{ns}} \mathrm{A}$ & $19.04^{\mathrm{ns}} \mathrm{A}$ & $12.95^{\text {ns }} \mathrm{A}$ & $11.62 \pm 0.08$ \\
\hline $2,4-\mathrm{D} 0$ & $24.91^{\mathrm{ns}} \mathrm{A}$ & $24.05^{\text {ns }} A$ & $20.60^{\text {ns }} A$ & $26.76 \pm 3.44$ \\
\hline $2,4-\mathrm{D} 1$ & $29.84^{\mathrm{ns}} A$ & $22.32^{\text {ns }} A B$ & $20.20^{\mathrm{ns}} B$ & $26.38 \pm 2.66$ \\
\hline 2,4-D 10 & $22.10^{\mathrm{ns}} \mathrm{A}$ & $25.34^{\mathrm{ns}} \mathrm{A}$ & $23.23^{\text {ns }} \mathrm{A}$ & $34.28 \pm 5.32$ \\
\hline $2,4-\mathrm{D} 50$ & $25.14^{\mathrm{ns}} \mathrm{A}$ & $21.85^{\mathrm{ns}} \mathrm{A}$ & $20.45^{\text {ns }} \mathrm{A}$ & $05.19 \pm 7.23$ \\
\hline 2,4-D 100 & $29.39^{\mathrm{ns}} A$ & $24.83^{\text {ns }} A B$ & $19.01^{\mathrm{ns}} \mathrm{B}$ & $31.65 \pm 6.44$ \\
\hline
\end{tabular}

Mean values followed by the same letters in the lines did not differ by the Tukey test $(p<0.05)$. Control $2=$ shoots collected on budding

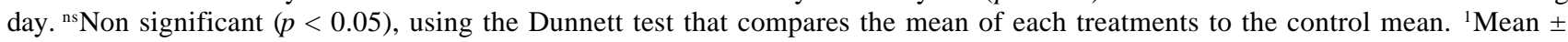
standard deviation. 
The GA treatment increased the starch concentrations in the bark of the 'Baianinha' cultivar (1.68\% for $\mathrm{GA}_{3}$, against $1.25 \%$ for NAA, and $1.28 \%$ for 2,4-D). Compared to the other cultivars, 'Baianinha' shoots treated with $\mathrm{GA}_{3}$ also showed the highest starch concentrations in the bark (1.68\%, against $1.23 \%$ for 'Valencia' and $1.19 \%$ for 'Murcott'). 'Murcott' tangor responded best to the 2,4-D treatment $(1.58 \%$ of starch). 'Valencia' orange had a decrease in starch concentration in the bark $(1.35 \%$, on average) as compared to the control $(1.59 \%)$.

The 2,4-D increased starch percentages in the wood of the three cultivars (3.04\% on average) as compared to the other regulators $(2.18 \%$ on average) and to the control (1.85\% on average), with the tangor 'Murcott' cultivar presenting the best response (3.19\%). This cultivar also responded best to the NAA and $\mathrm{GA}_{3}$ treatments $(3.06 \%$ and $2.29 \%$, respectively). Starch concentrations in the wood were higher than in the bark in the three cultivars $(2.31 \%$ in the wood and $1.4 \%$ in the bark, on average). Despite the variations observed, it was not possible to establish a relationship between total sugar percentages and bud viability. Maciel (2006) observed a reduction in carbohydrate concentration in shoots of two citrus cultivars after storage for 180 days, but bud viability was not affected. Gomes (2004) also did not find correlation between the concentration of total soluble sugars and starch, and bud viability of three citrus cultivars.

\section{CONCLUSIONS}

The budsticks of the cultivars 'Baianinha' and 'Valencia' sweet oranges and 'Murcott' tangor can be stored for 74 days at $5^{\circ} \mathrm{C}$ without loss of bud viability. The budsticks of the 'Tahiti' lime can also be stored for 74 days at $5^{\circ} \mathrm{C}$ without loss of bud viability, but it is necessary to reduce budstick deterioration. NAA and 2,4-D at concentrations of $200 \mu \mathrm{mol} \mathrm{L}^{-1}$ and $20 \mu \mathrm{mol}$ $\mathrm{L}^{-1}$, respectively, were efficient in controlling abscission of leaf petioles of budsticks of 'Valencia' sweet orange and 'Murcott' tangor. For 'Baianinha', the best concentration was $1000 \mu \mathrm{mol} \mathrm{L}{ }^{-1} \mathrm{NAA}$ and $100 \mu \mathrm{mol}$ $\mathrm{L}^{-1}$ 2,4-D. The use of NAA, GA 3 and 2,4-D for the treatment of 'Tahiti' budsticks stored under low temperature, aiming to control petiole abscission, was not required.

\section{ACKNOWLEDGEMENTS}

To CAPES and CNPq for financial support.

\section{REFERENCES}

ARTECA, R.N. Plant growth substances: principles and applications. New York: Chapman \& Hall, 1995. 332p.

BISSOLI, M.J.A.C. Estudo da conservação de borbulhas de quatro espécies cítricas (Citrus sp.) empregando diferentes processos de desinfecção. Piracicaba: USP/ESALQ, 1986. 61p. Dissertação (Mestrado).

BLUMER, S. Efeitos de revestimentos e acondicionamento em baixa temperatura na preservação pós-colheita de ramos portaborbulhas de laranjeira 'Pera' (Citrus sinensis L. OsbecK). Piracicaba: USP/ESALQ, 2000. 54p. Dissertação (Mestrado).

CASTRO, P.R.C.; VIEIRA, E.L. Aplicações de reguladores vegetais na agricultura tropical. Guaíba: Agropecuária, 2001.132p.

FUNDAÇÃO ARTHUR BERNARDES - FUNARBE. SAEG: sistema para análises estatísticas: v.5.0. Viçosa: FUNARBE, 1993.

GOMES, S.A. Conservação de hastes porta-borbulhas de citros de diferentes idades, em vários períodos de armazenamento. Viçosa: UFV, 2004. 48p.

HOGDE, J.E.; HOFREITER, B.T. Determination of reducing sugars and carbohydrates. In: WHISTLER, R.L.; WOLFROM, M.L. (Ed.) Methods in carbohydrate chemistry. New York: Academic Press, 1962. v.1, p.380-394.

LICHTEMBERG, L.A. Efeito de espaçamentos e porta-enxertos no crescimento das plantas e na concentração foliar de nutrientes, em laranjeira (Citrus sinensis (L.) Osbeck) cv. 'Valência'. Porto Alegre: UFRGS, 1981. 120p. Dissertação (Mestrado).

MACIEL, H.S. Viabilidade e frigoconservação de borbulhas de citros. Porto Alegre: UFRGS, 2006. 65p. Dissertação (Mestrado).

MARINI, R.P.; BYERS, R.E.; SOWERS, D.L.; YOUNG, R.W. Fruit abscission and fruit quality of apples following use of Dicamba to control preharvest drop. Journal of the American Society for Horticultural Science, v.115, p.390-394, 1990.

McCREADY, R.M.; GUGGOLZ, J.; SILVIERA, V.; OWENS, H.S. Determination of starch and amylose in vegetables: application to peas. Analytical Chemistry, v.22, p.1156-1158, 1950.

MEDEIROS, E.C. Uso de 2,4-D e de GA no controle da queda das laranjas 'Hamlin' e 'Baianinha'. Viçosa: UFV, 1997. 86p. Dissertação (Mestrado).

NAGAO, M.A.; SAKAI, W.S. Effects of growth regulators on abscission of young macadamia fruit. Journal of the American Society for Horticultural Science, v.110, p.654-657, 1985.

ORTEGA, J.L.C. Efeito do 2,4-D e Ethrel na queda e amadurecimento do fruto de café (Coffea arabica L.). Lavras: ESAL, 1983. 78p. Dissertação (Mestrado).

PATEL, R.Z. A note on the seasonal variations in starch content of different parts of arabica coffee trees. East African Agricultural and Forestry Journal, n.36, p.1-6, 1970.

RAMALHO SOBRINHO, R. Caracterização do surto de desenvolvimento primaveril em três espécies de citros. Lavras: ESAL, 1986. 106p. Dissertação (Mestrado).

TESSARIOLI NETO, J.; KLUGE, R.A.; JACOMINO, A.P.; SCARPARE, J.A.; IWATA, A.Y. Conservação de raízes de beterraba 'Early Wonder' em diferentes tipos de embalagens. Horticultura Brasileira, v.16, p.7-10, 1998.

TAIZ, L.; ZEIGER, E. Fisiologia vegetal. 3 ed. Porto Alegre: Artmed, 2004. 719p.

WIEN, H.C.; ZHANG, Y. Prevention of flower abscission in bell pepper. Journal of the American Society for Horticultural Science, v.116, p.516-519, 1991.

Received May 04, 2006

Accepted November 29, 2007 